\title{
The Influence of the Pandemic on the Motivation of EAP Learners in Studying IELTS
}

\author{
Nur Amalina Sari ${ }^{*}$, and Mualimin Mualimin ${ }^{2}$ \\ ${ }^{1}$ Department of Linguistics, Faculty of Humanities, Universitas Diponegoro, Semarang - 50273 Cental \\ Java, Indonesia \\ ${ }^{2}$ Department of Linguistics, Faculty of Humanities, Universitas Diponegoro, Semarang - 50273, Cental \\ Java, Indonesia
}

\begin{abstract}
Various sectors have been affected by the Covid-19 pandemic, including education. Many institutions have not yet applied face-to-face learning in full to prevent the transmission of the virus. The aims of this study are (1) to examine the motivation of EAP learners to learn IELTS in online and offline classes during a pandemic on an English course, and (2) to identify changes in student motivation during the learning process that are affected by the pandemic situation. This study uses a qualitative descriptive method with a sampling technique in which students are sampled randomly. As many as 10 students have been taken as participants. Furthermore, a questionnaire has been used as a data collection method, and it has been shared through Google Forms. It consists of 25 statements divided based on intrinsic and extrinsic motivation. The result of it has been classified based on four learning motivation aspects by Gowing's theory. Overall, the findings revealed that three of the four aspects of learning motivation are medium-level $(49,4 \%)$ in this case. In conclusion, there is no substantial motivation for EAP pupils in the English learning process, specifically for IELTS in online and offline sessions, for an ongoing pandemic.
\end{abstract}

\section{Introduction}

The Covid-19 pandemic has reached its second year, which began at the end of 2019 and is still being concerned in various countries. In Indonesia, the pandemic began in early March 2020 and is still ongoing, with a significant increase in positive cases of Covid-19 in various regions in Indonesia. This case has had a significant impact on many fields, such as economic, social, health, religious matter, education, etc. and as a result, many aspects have been changed considerably. Education is one of the areas that has been severely affected, so the government issued a Circular letter numbered 4 of 2020 concerning the implementation of education in the emergency period of the spread of Covid-19 (Arum \& Susilaningsih, 2020) [1]. In this case, the government continues to strive to reduce the rate of virus transmission, especially in learning activities in educational institutions.

\footnotetext{
*Corresponding author: amalinasari.nur92@gmail.com
} 
The letter regulates the online learning framework that must be applied. Although in the middle of the second year of the pandemic, the government will plan to re-open offline classes or face-to-face learning at educational institutions in certain areas, it seems that the transmission of the virus still threatens all parties.

This unstable situation raises several factors that affect both teachers and students teaching and learning experience. One of which is student motivation which is very important not only for the students learning in the online classroom but also for students who start learning in face-to-face classes.

Conceptions of psychological inspiration resemble those of ordinary language in several different respects. As there can be no precise observation of motivation, psychologists deduce motivation from aim-orientated behaviour. Multiple motivations usually stimulate outside or inside individuals (Kasschau, 2003) [2].

Referring to several previous studies regarding student learning motivation in the Covid19 pandemic situation, the researcher is going to present some of the results that previous researchers have conducted. The first is research conducted by Rahardjo \& Pertiwi (2020) [3] shows that the connection between student motivation for the learning of English and student performance was graded into the low category in the current covid-19 pandemic situation. Secondly, research conducted by Muslimin \& Harintama (2020) [4] shows a rise in students' motivations in online mode learning.

Next, Wahyudin et al. (2020) [5] research indicates a significant amount of student learning motivation in the high grade, with markers of having a positive outlook despite the pandemic condition. In the following research, Subakthiasih \& Putri (2020) [6] explains that students had more inherent motivation than extrinsic desire to learn English. It shows that the student's motivation was more significant than the outside motivation of students. According to Fitriyani et al. (2020) [7], there are at least eight measures of learning motivation in pupils, the outcomes of which can be shown by a very successful evaluation, where the proportion of the motivation score exceeds 80.27 per cent. Cahyani et al. (2020) [8] find that learning enthusiasm among students taking online courses has diminished during the Covid-19 virus pandemic. Then, Lestari (2020) [9] describes her study using JBClass as a tool for learning English during the pandemic, which culminates in a boost in student motivation.

In addition, Mandalina et al. (2021) [10] are using JASP tools in their research; then, it shows that online learning has significantly influenced learners' motivation and learning outcomes. However, not all online learning will improve students' enthusiasm and learning performances during the Covid-19 pandemic, owing to several obstacle factors in online learning. Furthermore, the research that has been done by Putri \& Winarta (2021) [11] and also Islam \& Putri (2021) [12] demonstrate the result in the same case and reveals that students are still strongly motivated to pursue online learning of English even during the pandemic.

From the description above regarding previous researches that discussed learning motivation during the pandemic in Indonesia, it can be concluded that most of the results of their research are an increase in motivation towards student learning with or without an online system.

The purpose of this research reported here is (1) to analyse the motivation of English for Academic Purpose (EAP) learners focusing on learning IELTS between online and offline classes at an English course, (2) to identify the impact of the pandemic both on the positive and negative sides on the student learning process. The findings of this analysis are intended to inform one of the current issues in education that are emerging as a result of the continuing pandemic. It is also hoped that this report will be used as a guide or reference for further research. 


\subsection{Definition of Motivation}

According According to Feldman (2009) [13], motivation is defined as "the factors that direct and energize the behaviour of humans and other organisms". He added that motivation has biological, cognitive, and social dimensions, and psychologists create a range of techniques because of the scope of the term. They are all about explaining the force that drives the actions of people in particular directions.

Furthermore, Masgoret and Gardner (2003) [14] explain that motivation is described as goal-oriented behaviour (cf. Heckhausen, 1991). When attempting to quantify motivation, the focus may be directed toward a variety of individual characteristics. The motivated person exerts effort, is diligent and committed to the job at hand, has ambitions, expectations, and dreams, enjoys the exercise, receives reinforcement from achievement and dissatisfaction from failure, makes attributions about success and/or defeat, is aroused, and employs tactics to assist in target attainment. Moreover, Kasschau (2003) [2] believes that motivation covers different psychological and physiological factors that cause someone to behave in a certain way.

\subsection{Types of Motivation}

Ur (1991) [15] divides the types of motivation into three points, among others; (1) integrative and instrumental motivation, (2) intrinsic and extrinsic motivation, and (3) global, situational, and task motivation (this point was made by Brown (1987) and added to the categories Ur summarized).

Besides, the cognitive approach to the philosophy of motivation suggests that motivation results from the thinking and desires of individuals. This theory then distinguishes between intrinsic motivation and extrinsic motivation (Feldman, 2009) [13]. So, based on the theory above, the researcher is going to identify both types of motivation:

\section{1) Intrinsic Motivation}

According to Ryan (1993), intrinsically motivated behaviour creates an integration and internalization mechanism. The propensity to incorporate individuals will lead people to do what they want, internalize and accept these actions' values, and feel separate and linked to others in the social environment (Hayamizu, 1997) [16]. However, intrinsically motivated behaviours are that those activities are personally valuable or because our values or desires satisfy them (Kasschau, 2003) [2].

The motivations that are intrinsically driven are those for which the behaviour itself is no seeming benefit. People tend to participate in the events for their benefit rather than for the sake of an extrinsic reward. The tasks are intended to be ends in themselves rather than a means to an end (Deci, 1976) [17].

\section{2) Extrinsic Motivation}

Kasschau (2003) [2] defines extrinsic motivation as eliminating or including benefits or additional rewards of biological needs. While extrinsic motivation, defined by Ur (1991) [15], explained that it comes from the power of an implicit encouragement that is different from the need to think about yourself or become interested in the job itself. Islam \& Putri (2021) explain extrinsic factors, such as: (1) environmental condition of the learners, (2) job demands, (3) the parent wishes, (4) other encouragement, and (5) efforts from the lecturers in teaching. 


\subsection{Characteristics of Motivated Students}

Some characteristics of motivated pupils that have been mentioned by Ur (1991) [15] are:

1) Positive task orientation. The pupil is eager to take on assignments and obstacles and is confident in his or her ability to succeed.

2) Ego-involvement. It is vital to the learner to achieve in learning in order to preserve and encourage his or her own (positive) personality.

3) Need for achievement. The pupil has a strong desire to excel, to conquer obstacles and to accomplish his or her goals.

4) High aspirations. The pupil is competitive, seeking difficult tasks, high proficiency, and high marks.

5) Goal orientation. The student is very mindful and focuses his or her attempts to achieve their objectives of learning or of particular learning experiences.

6) Perseverance. The student regularly puts in a high degree of commitment in his or her studies and is not distracted by failures or perceived lack of success.

7) Tolerance of ambiguity. Situations containing a transient loss of comprehension or misunderstanding need not disturb or frustrate the student; he or she can deal with these calmly, certain that understanding will occur later.

\subsection{English for Academic Purpose (EAP)}

EAP's scope according to Hyland and Hamp-Lyons state as "the linguistic, sociolinguistic and psycholinguistic description of English as it occurs in the contexts of academic study and scholarly exchange itself". In addition, this emphasis on scholarly contexts distinguishes EAP from ESP, but within applied linguistics and English language teaching fields more broadly, the perception of EAP as a sub-discipline within ESP persists (Hamp-Lyons, 2011) [18].

\subsection{The International English Language Testing System (IELTS)}

The official website of IELTS (https://www.ielts.org) [19] explains that The International English Language Testing System (IELTS) is intended to assist you in working, studying, or migrating to a country where English is the native language. This covers Australia, Canada, New Zealand, the United Kingdom, and the United States. The ability to speak in the native language of the nation in which you wish to work or study has many advantages. It is also essential for work openings and group integration. It is recognized by over 10,000 employers, colleges, schools, and immigration bodies worldwide, including 3,400 institutions in the United States. During the exam, all of the skills in English will be evaluated. The IELTS exam is scored on a scale of 1-9. IELTS is divided into two categories: Academic and General Training. Both assessments measure the ability to communicate in English by Listening, Reading, Writing, and Speaking.

Moreover, Davies et al. (2006) [20] define IELTS as a battery of tests designed to determine the language proficiency of non-native English speakers pursuing admission to English-medium courses in institutions of higher or further education.

\section{Research Method}

The study uses qualitative methods, employing qualitative descriptive data processing tools to explain the research findings. Moleong (2006) says that qualitative research aims at understanding the phenomena of study topics as behaviour, perception, motivation, action 
etc. Holistic perspective, in a particular context and through numerous natural approaches, the description is used in terms of words and language (Islam \&Putri, 2021) [12].

In addition, the researcher chose the questionnaire to be used as an instrument to assess students' drive to learn English, especially IELTS. In the data collection process, with 25 statements relating to the two kinds of motivation consisting of 10 statements of intrinsic motivation, 10 others going into extrinsic motivation, others out of intrinsic and extrinsic motivation, and also mixing with theory from Gowing (2001) [21] about four points of learning motivation aspects.

Furthermore, Gardner's attitude and motivation have categorized the responses collected from the participants into five groups: strongly agree, agree, neutral, disagree and strongly disagree (Putri \& Winarta, 2021) [11]. Students have to answer questions from a specified questionnaire, and they have a substantial choice of Strongly Agree, Agree, Neutral, Disagree and Strongly Disagree.

Then, the questionnaire through the Google Forms media has been circulated to participants to help promote the testing process and prevent the dissemination of the Covid19 virus, which is deadly, without meeting them face to face. In addition, the form of a diagram, notably Pie charts, the result of respondents has been interpreted automatically with the percentages of Google Forms. To assist these automatic evaluations, the researcher has incorporated an interval table of criteria for the score interpretation based on Fitriyani et al. (2020) [7] that has been subsequently characterized the percentages of findings based on five categories, including very high, high, moderate, low, and very low.

Table 1. Percentage Interpretation Criteria

\begin{tabular}{|c|c|}
\hline Percentage & Category \\
\hline $80 \%-100 \%$ & Very High Motivation \\
\hline $60 \%-79,99 \%$ & High Motivation \\
\hline $40 \%-59,99 \%$ & Moderate Motivation \\
\hline $20 \%-39,99 \%$ & Low Motivation \\
\hline $0 \%-19,99 \%$ & Very Low Motivation \\
\hline
\end{tabular}

Participants in this study are students studying at the English Studio, one of the IELTSspecific English courses located in Kampung Inggris, Pare, Kediri, East Java, Indonesia. The researcher randomly takes 10 students from online and offline classes as a sample. The researcher's reason does not take a large number of participants to be sampled, due to the number of students between online and offline classes is not the same, so to balance the assessment in the analysis of this study, the same number is needed, and the researcher takes the minimum number that has been deemed sufficient to continue the mini-research.

\section{Result and Discussion}

\subsection{Finding}

The study's objective is to determine and analyse the motivation of IELTS students during an English-Studio Pandemic in online and offline courses. Concerning the second year of the pandemic, the course has reopened offline or face-to-face learning. In contrast, as stated by the Management, the course shows there has been a decrease in the number of students taking part in the offline course, but it shows that they are motivated to gain insight, which they naturally want to study IELTS. 
Definition of learning motivation, according to Kim et al. (2016), is that individuals eager to learn aim to glean as much as they can from educational/training programs and are willing to work hard to develop their abilities and competencies for learning objectives. Moreover, the learning motivation definition that Cheng \& Ho (2011) claim is as a learner's unique desire to learn the material of a training program (Roebroek, 2018) [22]. However, some researchers (Porath, Spreitzer, Gibson, \& Garnett, 2012 and Lin, 2015) in the same assumption about the meaning of motivation to learn that has been defined as the amount of effort that an individual puts forth in the development of personality.

The researcher has seen this phenomenon considered to find out how much motivation they have to learn in this pandemic when the health protocol limits all space for movement. This has led researchers increasingly to seek additional information through surveys carried out by using a remote questionnaire in an online survey. The earliest questions on the questionnaire are related to their main goals in studying IELTS. The following results can be seen in Figure 1 below.

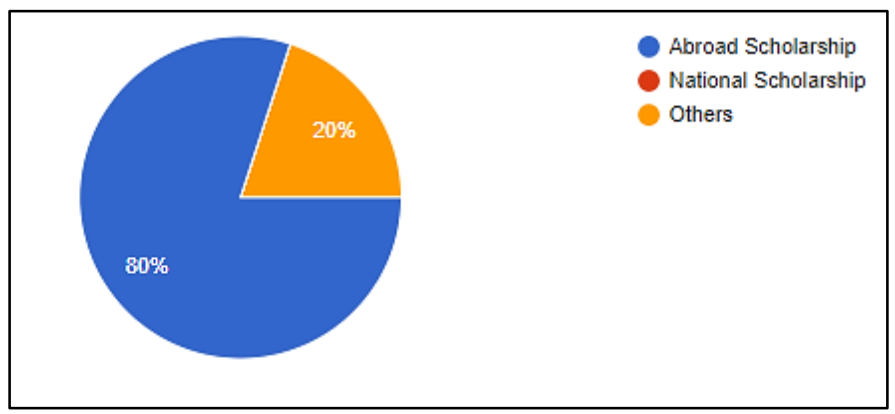

Fig. 1. The Main Goal in Learning IELTS.

The pie chart compares the proportion of the students' primary purpose in learning IELTS. Overall, it can be seen that the most popular answer is Abroad scholarship which is presenting at four-fifths $(80 \%)$ which is far higher than for others percentage only at a fifth. They have answered that scholarship abroad is their primary goal to continue their education; the rest has answered that they have other goals than that.

This case can relate to the goals of the researcher who make them EAP students who focus on academic goals. English for Academic Purposes (EAP) offers a detailed perspective on the philosophy and application of English for academic purposes (EAP), focusing on the specification of learners' needs and research skills that match their needs (Jordan, 1997) [23]. Hyland (2006) [24] claims that EAP appears to be a realistic solution to the needs of a specific group of students at first sight. However, EAP encompasses micro areas of the academic, communicative experience from classroom engagement to students' writing and not forgetting study genres managerial activities. These fields of academic, communicative practice include more than polishing written form.

Furthermore, the researcher will classify and describe the survey results from the questionnaire. According to Gowing (2001) [21], who has divided four points of learning motivation aspects, those are:

a. Achievement. An effort to have an urge to be able to increase or meet standards of excellence in order to achieve goals.

b. Commitment. Something that is in line with the goals the student wants to achieve in a consistent manner.

c. Initiative. Preparations made to follow up existing opportunities by creating new ideas so that goals are met. 
d. Optimism. Persistence in pursuing goals even though they have to face obstacles and obstacles, but they are still lived and passed without feeling a burden

While the explanation is divided into indicators, aspects, percentages and categories, all presented in table form below.

Table 2. The Questionnaire Result

\begin{tabular}{|c|c|c|c|c|c|c|c|}
\hline \multirow{2}{*}{ Aspect } & \multirow{2}{*}{ Indicator } & \multicolumn{5}{|c|}{ Percentage } & \multirow[t]{2}{*}{ Category } \\
\hline & & $\mathbf{S A}$ & $\mathbf{A}$ & $\mathbf{N}$ & D & SD & \\
\hline \multirow{8}{*}{$\begin{array}{c}\mathbf{A} \\
\mathbf{C} \\
\mathbf{H} \\
\mathbf{I} \\
\mathbf{E} \\
\mathbf{V} \\
\mathbf{E} \\
\mathbf{M} \\
\mathbf{E} \\
\mathbf{N} \\
\mathbf{T}\end{array}$} & Have a desire and effort to & 60 & 20 & 10 & - & 10 & High \\
\hline & $\begin{array}{l}\text { practice and improve the English } \\
\text { skills at the advance level. }\end{array}$ & $\%$ & $\%$ & $\%$ & & $\%$ & Motivation \\
\hline & Have a desire and effort to look & 60 & 40 & - & - & - & High \\
\hline & $\begin{array}{l}\text { for a tutor to get better } \\
\text { understanding and also guidance } \\
\text { in learning IELTS. }\end{array}$ & $\%$ & $\%$ & & & & Motivation \\
\hline & Have a desire and effort to & 60 & 20 & 20 & - & - & High \\
\hline & $\begin{array}{l}\text { achieve the score's goal as one } \\
\text { of the scholarship requirements. }\end{array}$ & $\%$ & $\%$ & $\%$ & & & Motivation \\
\hline & Get satisfied with the IELTS & 10 & 10 & 60 & 20 & - & Neutral \\
\hline & $\begin{array}{l}\text { learning results obtained by } \\
\text { online courses. }\end{array}$ & $\%$ & $\%$ & $\%$ & $\%$ & & \\
\hline & \multirow{3}{*}{ Mean } & 47. & 22 & 22 & 5 & 2.5 & Moderate \\
\hline & & $5 \%$ & .5 & .5 & $\%$ & $\%$ & Motivation \\
\hline & & & $\%$ & $\%$ & & & \\
\hline & Able to concentrate or focus in & - & 40 & 30 & 20 & 10 & Moderate \\
\hline $\begin{array}{l}\mathbf{C} \\
\mathbf{O}\end{array}$ & $\begin{array}{l}\text { class while online learning is } \\
\text { ongoing. }\end{array}$ & & $\%$ & $\%$ & $\%$ & $\%$ & Motivation \\
\hline $\mathbf{M}$ & Ignore any distractions around the & 40 & 20 & 40 & - & - & Moderate \\
\hline $\mathbf{M}$ & learning process ongoing. & $\%$ & $\%$ & $\%$ & & & Motivation \\
\hline $\mathbf{I}$ & The passion for learning IELTS & - & 60 & 40 & - & - & High \\
\hline $\mathbf{T}$ & has remained consistent and has & & $\%$ & $\%$ & & & Motivation \\
\hline M & not fluctuated during the & & & & & & \\
\hline $\mathbf{E}$ & pandemic. & & & & & & \\
\hline $\mathbf{N}$ & The progress in learning IELTS & 30 & 30 & 30 & - & 10 & Low \\
\hline \multirow[t]{4}{*}{$\mathbf{T}$} & $\begin{array}{l}\text { has improved over time during } \\
\text { the pandemic. }\end{array}$ & $\%$ & $\%$ & $\%$ & & $\%$ & Motivation \\
\hline & \multirow{3}{*}{ Mean } & 17. & 37 & 35 & 5 & $5 \%$ & Low \\
\hline & & $5 \%$ & .5 & $\%$ & $\%$ & & Motivation \\
\hline & & & $\%$ & & & & \\
\hline I & Apply IELTS study opportunities & 70 & 30 & - & - & - & High \\
\hline $\mathbf{N}$ & for a quality future career. & $\%$ & $\%$ & & & & Motivation \\
\hline I & Fill in a spare time to study & 40 & 20 & 30 & 10 & - & Moderate \\
\hline $\mathbf{T}$ & IELTS outside of class time & $\%$ & $\%$ & $\%$ & $\%$ & & Motivation \\
\hline $\mathbf{I}$ & Doing communication with a & 50 & 40 & 10 & - & - & Moderate \\
\hline $\begin{array}{l}\mathbf{A} \\
\mathbf{T}\end{array}$ & $\begin{array}{l}\text { teacher when get a problem in } \\
\text { learning. }\end{array}$ & $\%$ & $\%$ & $\%$ & & & Motivation \\
\hline $\mathbf{I}$ & Prefer taking a course to learn & 30 & 40 & 20 & - & 10 & Low \\
\hline $\begin{array}{l}\mathbf{V} \\
\mathbf{E}\end{array}$ & IELTS intensively even in & $\%$ & $\%$ & $\%$ & & $\%$ & Motivation \\
\hline
\end{tabular}




\begin{tabular}{|c|c|c|c|c|c|c|c|}
\hline & Mean & $\begin{array}{l}47 . \\
5 \%\end{array}$ & $\begin{array}{l}33 \\
.5 \\
\%\end{array}$ & $\begin{array}{l}15 \\
\%\end{array}$ & $\begin{array}{l}2.5 \\
\%\end{array}$ & $\begin{array}{l}2.5 \\
\%\end{array}$ & $\begin{array}{c}\text { Moderate } \\
\text { Motivation }\end{array}$ \\
\hline \multirow{5}{*}{$\begin{array}{c}\mathbf{O} \\
\mathbf{P} \\
\mathbf{T} \\
\mathbf{I} \\
\mathbf{M} \\
\mathbf{I} \\
\mathbf{S} \\
\mathbf{M}\end{array}$} & $\begin{array}{l}\text { Have a strong desire to learn } \\
\text { IELTS of own eagerness. }\end{array}$ & $\begin{array}{l}50 \\
\%\end{array}$ & $\begin{array}{l}50 \\
\%\end{array}$ & - & - & - & $\begin{array}{l}\text { Moderate } \\
\text { Motivation }\end{array}$ \\
\hline & $\begin{array}{l}\text { Always enjoy each step on } \\
\text { learning IELTS even though } \\
\text { during pandemic situation. }\end{array}$ & $\begin{array}{l}50 \\
\%\end{array}$ & $\begin{array}{l}20 \\
\%\end{array}$ & $\begin{array}{l}10 \\
\%\end{array}$ & $\begin{array}{l}20 \\
\%\end{array}$ & - & $\begin{array}{l}\text { Moderate } \\
\text { Motivation }\end{array}$ \\
\hline & $\begin{array}{l}\text { Interested in learning IELTS } \\
\text { because it is able to develop a } \\
\text { positive mindset. }\end{array}$ & $\begin{array}{l}60 \\
\%\end{array}$ & $\begin{array}{l}30 \\
\%\end{array}$ & $\begin{array}{l}10 \\
\%\end{array}$ & - & - & $\begin{array}{c}\text { High } \\
\text { Motivation }\end{array}$ \\
\hline & $\begin{array}{l}\text { Keep the enthusiasm for taking } \\
\text { offline learning despite the } \\
\text { limitations of regulations } \\
\text { regarding health protocols during } \\
\text { the pandemic }\end{array}$ & $\begin{array}{l}37 . \\
5 \%\end{array}$ & - & $\begin{array}{l}62 \\
.5 \\
\%\end{array}$ & - & - & Neutral \\
\hline & Mean & $\begin{array}{l}49 . \\
4 \%\end{array}$ & $\begin{array}{l}25 \\
\%\end{array}$ & $\begin{array}{l}20 \\
.6 \\
\%\end{array}$ & $\begin{array}{c}5 \\
\%\end{array}$ & - & $\begin{array}{l}\text { Moderate } \\
\text { Motivation }\end{array}$ \\
\hline
\end{tabular}

$\begin{array}{ll}\text { Notes } & \text { : } \\ \text { SA } & \text { : Strongly Agree } \\ \text { A } & \text { : Agree } \\ \text { N } & \text { : Neutral } \\ \text { D } & \text { : Disagree } \\ \text { SD } & \text { : Strongly Disagree }\end{array}$

\subsection{Discussion}

\subsubsection{Achievement}

The table shows the data has obtained and presented above, and we can identify one by one based on the order of Gowing's (2001) [21] aspect. At first glance, it is an achievement, which this point is important in student learning motivation because the efforts are made the first step of students in achieving their goals. The driving force for achievement was conceptualized by McClelland (1961) as a generally consistent and learnt tendency of the psyche that motivates persons to achieve their own internalized excellence standards and strive for success (Negovan \& Bogdan, 2013) [25]. As for indicators of this aspect, there are 4 items, including (1) having a desire and effort to practice and improve the English skills at the advanced level, (2) having a desire and effort to look for a tutor to get a better understanding, and also guidance in learning IELTS, (3) have a desire and effort to achieve the score's goal as one of the scholarship requirements, and (4) get satisfied with the IELTS learning results obtained by online courses. Points 1 up to 3 has the same percentages, approximately $60 \%$ in the Strongly Agree answer, which means high category motivation. While, point 4 shows that the highest one is about $60 \%$ in neutral choice, while a minority percentages (10\%) of students answered in Strongly Agree or Agree. So that, students do not have high satisfaction in their learning result as long as learning via daring. We may take the average value of the percentage in this aspect, which is as much as $47.5 \%$ of the most significant total in the Strongly Agree with response options, and define it as Moderate Motivation if it meets the score interpretation requirements. 


\subsubsection{Commitment}

Secondly, commitment is one component that a person must also consider to reach his goals. Without a firm commitment, actions are not taken, and each process has a reason not to be in a position to prevent any existing disruptions or issues. Previously, Meeus (1996) defined commitment as the amount to which young people feel dedicated to and receive selfassurance from a good self-image and future confidence from relationships (Korpershoek, 2016) [26]. In contrast, Johansson \& Rönkkö (2004) [27] suggest that commitment is an essential aspect of corporate culture and driver in daily work. It fosters creativity by emphasizing active and voluntary responsibility and the need to take action on the part of each employee. Nevertheless, the notion of commitment is an essential learning principle.

The student's approach to their future job is practical, professional and demanding. Then, commitment is the second aspect Gowing (2001) [21] mentions; the researcher observes four indicators to target respondents. In the first indicator about concentrating or focusing on learning, most students have been answered. Agree as much as two-fifths higher than answer Disagree at only a fifth. Meanwhile, an indicator of neglect distraction has a percentage at $20 \%$ in Agree that lower than two choices answer between Strongly Agree and Neutral at $40 \%$ respectively. Nevertheless, the most significant proportion of passion for learning IELTS in this aspect covered in the 4 answer choices is Agree approximately 60\%, and only two-fifths shows Neutral. It can include the high motivation category because more than half of students still have a passion for learning IELTS during the pandemic. So, the last indicator displays the unique case because three of the answer choices have the same percentage, those are about less than a third (30\%) severally among $S A, A$, and $N$. the remaining $10 \%$ is allocated to $S D$. It seems that pupils' progress in learning has no strong motivation, as this number demonstrates; therefore, this is part of low motivation.

\subsubsection{Initiative}

Robitschek Robitschek (1998) states that personal growth initiative as the active involvement of an individual in the process of personal growth and is linked with the activity of individuals, their understanding of personal development opportunities, and their intentionality and awareness of changes in their own lives (Negovan \& Bogdan, 2013) [25]. This aspect has four items which the researcher divides into the questionnaire. The result reveals that most learners chose to take IELTS for having a future career with good quality, so that is high motivation criterion because it can be proven by the number that increased by seven in ten (70\%) which covered all choices' answers. Different from above, in this part, students' initiative to use their free time to study IELTS shows a moderate level in motivation; hence only $40 \%$ answered $S A$ and other items just under less than a third percentage.

The following, making communication with teachers give proportion as much as approximately $50 \%$ for $S A$ and $40 \%$ for $A$, which are slight differences. It means including moderate motivation. Creating engagement with the teacher might be difficult for sure pupils if they do not have a strong desire to learn. The latest figure exposes moderate to low motivation about taking a course as a learning facility intensively during pandemic contains four items of equal answer choices that make up among one in ten up to two-fifths. Then, the highest percentage is allocated in Agree choices. It may be concluded that some pupils prefer to study IELTS privately or choose to take a course institution online. 


\subsubsection{Optimism}

In the last learning motivation aspect, here is optimism. Before the researcher explains the result, it is better to review optimism. As Nasab et al. (2015) [28] cite optimistic understanding from various sources of researchers, some of them are Carver and Scheier (2002) note that optimism is favourable for the future. While optimism, according to Peterson and Park (2004), optimism indicates the state of knowledge, feeling, and future motivation. However, Noori and Janbozorgi (2008) state that the optimistic documentation approach will boost good feelings like optimism and pride after achievement and remove fear and anxiety.

The optimism findings that indicate the average percentage of indicators assure that the category to be finished is modest in this last feature can be noticed from the table. In addition, one by one of the indications will be described. The first is because of the strong want of students to learn from themselves, that they have 2 responses and that they Strongly agree and Agree with each other, both of which are of precisely the same value is a half per cent. Therefore, this value can be classed as moderate, with the figure a half $(50 \%)$ per cent as indicated in table 1 above.

Secondly, concerning the indicator, which states that students can enjoy every process of learning IELTS even during the pandemic, it provides the same results as the previous indicators that entered the modest motivation class, as explained by most answers. Notably, 50 per cent answered Strongly Agree, the rest answered less than 30 per cent to Agree, Neutral, or Disagree.

Moreover, the pupils' interest in learning IELTS, which is assumed to be able to develop positive thinking, is demonstrated by survey results in which as many as $60 \%$ of them answered Strongly Agree, indicating that they continue to have high motivation, which is supplemented by around 30\% of other students who chose to answer Agree, further strengthening the classification results of the category at a high level.

Unfortunately, different aspects of the enthusiasm of students for face-to-face learning which resulted in a low percentage or almost half of the previous percentage of students in the choice of $S A$ responded; however, the neutral response has shown that there are twice as many as the number of students in the $S A$ system, notably just over three-fifths (62.5\%). This shows the motivation of neutrality or may be part of the moderate group in which health protocols are in a restricted pandemic situation to make everyone uncomfortable when they teach and learn in face-to-face classes. Some learners and others are not opposed to these policies. Moreover, from the original point of view, we must perceive their drive to reach targets that cannot be appraised on the one hand just with a sense of optimism in some places.

\section{Conclusion}

The finding of the research has been reported in the discussion and findings' chapter above. It can be inferred that the motivation of English for Academic Purposes (EAP) students learning IELTS at the English Studio, Kampung Inggris, Pare, East Java, Indonesia is in average or medium level. The explanation is as follows: (1) approximately $47.5 \%$ were identified in the Achievement aspect, (2) the Commitment aspect was a low, roughly $37,5 \%$, (3) the Initiative aspect is as same as Achievement proportion, that is around $47.5 \%$, then the last (4) the percentage indicates the highest percentage of the preceding three aspects, about $49.4 \%$ and still falls into the moderate level. These findings, therefore, reflect the average total value of three elements, which has a value of about $50 \%$, and it specifies the category of moderate motivation.

Suppose the pandemic has a natural effect on student motivation. In that case, students have discomforts in the online and offline learning procedure and reduced student enthusiasm due to the space limitation in offline classrooms because of government-implemented health 
protocol regulations. The findings of this investigation, therefore, demonstrated the actual situation in the current institutional pandemic.

\section{References}

1. A.E. Arum, E. Susilaningsih, Pembelajaran Daring dan Kajian Dampak Pandemi Covid-19 di Sekolah Dasar Kecamatan Muncar, in Proceedings of Postgraduate National Seminar (Prosnampas), $21^{\text {st }}$ February 2021, Semarang, Indonesia (2020)

2. R.A. Kasschau, Understanding Psychology. (2003)

3. A. Rahardjo, S.Pertiwi, L.M.S.A.L.E: A.C.S.S.S.S.C.P.S. 1, 56-64 (2020)

4. A.I. Muslimin, F. Harintama, O.L.D.P: S.M.C.A. 13, 60-68 (2020)

5. W. Wahyudin, M. Maharida, E. Jusriadi, S. Syafarudin, A.M.H.S.L.P. 9, 259-273 (2020)

6. P. Subakthiasih, I.G.A.V.W. Putri, A.S.M.S.E.D.C.P. 4, 126-141 (2020)

7. Y. Fitriyani, I. Fauzi, M.Z. Sari, M.B.M.P.D.S.P.C. 6, 165-175 (2020)

8. A. Cahyani, I.D. Listiana, S.P.D.Larasati, M.B.S.S.P.D.M.P.C. 3, 123-140 (2020)

9. Y. Lestari, P.J.U.M.M.B.B.I.P.D.S.M.P.C. 5, 114-122 (2020)

10. V. Mandalina, Syahruddin, D. Pramita, Ibrahim, Haifaturrahmah, P.D.M.M.H.B.P.D.S.P.C: S.M-A. 3, 120-129 (2021)

11. I.G.A.V.W. Putri, I.B.G.N. Winarta, I.M.E.O.L.D.P.C. 4, 23-33 (2021)

12. H. Islam, D.G. Putri, The Online Learning Motivation of English Language Education Students in Covid-19 Pandemic Era, in Proceedings of National Seminar of PBI, NSPBI, $24^{\text {th }}$ February 2021, Pekalongan, Indonesia (2021)

13. R. S. Feldman, Essentials of Understanding Psychology, Eighth Ed. (2009)

14. A.M. Margoret, R.C Gardner, A.M.A.S.L.L: A.M-A.S.C.B.G.A.A. 53, 123-163 (2003)

15. P. Ur, A Course in Language Teaching: Practice and Theory. (1991)

16. T. Hayamizu, B.I.E.M: E.R.A.S.B.T.T.I. 39, 98-108. (1997)

17. E.L. Deci, Intrinsic Motivation. (1976)

18. L. Hamp-Lyons, English for Academic Purposes, in Handbook of Research on Second Language Learning and Teaching. (2011)

19. IELTS. (2021, Juli). Retrieved from https://www.ielts.org/about-ielts/what-is-ielts

20. A. Davies, A. Brown, C. Elder, Dictionary of Language Testing. (2006)

21. M.K. Gowing, M.I.E.C, in The Book of The Emotionally Intelligent Workplace: How to Select for, measure, and improve emotional Intelligence in Individuals, Group, and Organization. (2001)

22. M. Roebroek, T.E.C.C.M.T.L. Literaure review of Bachelor thesis. (2018)

23. R.R. Jordan, English for Academic Purposes: A Guide and Resource Book for Teachers. (1997)

24. K. Hyland, English for Academic Purposes: An Advanced Resource Book. (2006)

25. V. Negovan, C. Bogdan, L.C.U.S.N.F.A.C.A.M.P.G.I. 78, 300-304 (2013)

26. H. Korpershoek, R.A.M.C.C.C.A.S.E. 4, 28-43 (2016)

27. C. Johansson, K. Rönkkö, Commitment as the Underlying Principle for Learning, in Proceedings of the $6^{\text {th }}$ Joint Conference on Knowledge-Based Software Engineering, JCKBSE, Protvino, Russia August 25-27, 129-138. (2004)

28. S.H. Nasab, A. Asgari, M. Ayati, T.R.B.A.O.A.M.A.A.W.R.M.R.A.E.T.S.G.S. 5, 707$722(2015)$ 